Jurnal Oarotech 10 (2) 48-53, Desember 2020

e-ISSN : 2621-7236

p-ISSN : 1858-134X

\title{
PENANGANAN PASCA PANEN DENGAN METODE PENYIMPANAN UNTUK MENGHASILKAN BENIH PADI GOGO (Oryza sativa L.) LOKAL YANG BERKUALITAS
}

\section{POST-HARVEST HANDLING WITH STORAGE METHODS TO PRODUCE UPLAND RICE SEEDS (Oryza sativa L.) LOCAL QUALITY}

\author{
Mustakim $^{1 *}$, Abd Syakur ${ }^{1}$, Moh. Adnan Khaliq ${ }^{1}$, Yusran ${ }^{2}$ \\ ${ }^{1}$ Program Studi Agroteknologi Fakultas Pertanian Universitas Tadulako \\ ${ }^{2}$ PLP Fakultas Pertanian Universitas Tadulako \\ Jln. Soekarno Hatta Km. 9 Palu 94118 Sulawesi Tengah Indonesia
}

\begin{abstract}
ABSTRAK
Penanganan pasca panen sangatlah penting dilakukan untuk menghasilkan benih bermutu dan berkualitas. Tujuan dari penelitian ini ialah untuk mendapatkan penanganan pasca panen terbaik dengan metode penyimpanan yang berbeda untuk menghasilkan benih yang bermutu dan berkualitas dengan perkecambahan terbaik. Penelitian ini dilaksanakan di Desa Tamarenja (Lembah Kalama), Kecamatan Sindue Tobata, Kabupaten Donggala dan pengujian benih dilaksanakan di Laboratorium Ilmu dan Teknologi Benih, Fakultas Pertanian, Universitas Tadulako. Penelitian ini dilaksanakan pada bulan Oktober 2019 sampai Februari 2020. Penelitian ini disusun menggunakan racangan acak kelompok (RAK) pola faktorial dua faktor, faktor pertama terdiri atas dua tempat penyimpanan yaitu: P1= Dalam ruangan, $\mathrm{P} 2=$ Luar ruangan, Sedangkan faktor kedua terdiri atas tiga waktu penyimpanan yaitu: $\mathrm{W} 1=$ satu bulan dan $\mathrm{W} 2=$ dua bulan, dan $\mathrm{W} 3=$ tiga bulan, yang diulang sebanyak enam kali sehingga terdapat 36 unit percobaan dimana setiap unit percobaan terdiri 50 benih dengan total benih yang digunakan ialah sebanyak 1.800 benih. Analisis data menggunakan uji Fisher dan dilanjutkan dengan uji BNJ taraf 1\%. Hasil penelitian menunjukkan bahwa hasil panen yang disimpan dengan cara digantung diluar ruangan selama tiga bulan menghasilkan daya berkecambah $(71,00 \%)$, waktu berkecambah $(2,23$ hari), persentase benih berjamur $(9.33 \%)$, dan persentase kecambah berjamur $(9.33 \%)$.
\end{abstract}

Katakunci: benih berkualitas, padi gogo, penyimpanan, dan pasca panen

\section{ABSTRACK}

Post harvest handling is very important to produce quality and high quality seeds. The purpose of this study was to obtain the best post-harvest handling with different storage methods to produce quality and quality seeds with the best germination. This research was conducted in Tamarenja Village (Kalama Valley), Sindue Tobata District, Donggala Regency and seed testing was carried out at the Seed Science and Technology Laboratory, Faculty of Agriculture, Tadulako University. This research was conducted from October 2019 to February 2020. This research was arranged using a two-factor factorial randomized block design (RBD), the first factor consisting of two storage areas, namely: $P 1=$ indoors, $P 2=$ outdoors, while the second factor consists of three storage times, namely: W1 = one month and W2 = two months, and $W 3=$ three months, which was repeated six times so that there were 36 experimental units where each experimental unit consisted of 50 seeds with a total of 1,800 seeds used. Data analysis used Fisher's test and continued with the BNJ test at $1 \%$ level. The results showed that the yields stored by hanging outdoors for 3 three months resulted in germination (71.00\%), germination time (2.23 days), percentage of moldy seeds (9.33\%), and percentage of moldy sprouts (9.33\%).

keywords: Quality seeds, upland rice, storage, and post harvest

\footnotetext{
${ }^{*}$ Penulis Korespondensi.

E-mail: takimcfc@gmail.com

Telp: +62-82292768489
} 


\section{Pendahuluan}

Produksi beras di Indonesia setiap tahun terus mengalami penurunan yang diakibatkan oleh pengalihfungsian lahan menjadi tempat permukiman, industri dan yang lainnya. Disisi lain kebutuhan beras masyarakat Indonesia setiap tahunnya terus mengalami peningkatan yang diakibatkan oleh peningkatan jumlah penduduk yang terus meningkat dari tahun ke tahun, (Samudin, et al., 2020; Sutaryo dan Pamungkas, 2019).

Perluasan dan pengembangan padi gogo merupakan alternatif yang tepat untuk dapat memenuhi kebutuhan pangan masyarakat Indonesia. Padi gogo memiliki banyak keunggulan diantaranya ialah dapat tumbuh dilahan marginal dan tidak memerlukan teknologi yang super mewah untuk membudidayakannya. Masalah yang sering dihadapi dalam membudidayakan padi gogo ialah produktivitasnya masih rendah di bandingkan padi sawah, (Samudin et al., 2020; Sarwanto et al., 2018; Putra et al., 2014).

Rendahnya produktivitas padi gogo disebabkan oleh kurangnya benih bermutu, sehingga masyarakat hanya menggunakan benih asalan dalam pembudidayaan padi gogo. Benih yang bermutu merupakan salah satu penentu keberhasilan suatu tanaman untuk mendapatkan produksi yang tinggi. Penanganan pasca panen yang baik dapat menghasilkan benih bermutu dengan kualitas terbaik.

Penanganan pasca panen untuk menghasilkan bahan tanam selanjutnya (benih) sangatlah pengting mengingat gebah yang baru dipanen masih memiliki kadar air yang cukup tinggi, sehingga diperlukan penanganan khusus untuk menurunkan kadar air dan mempertahankan mutu serta kualitas benih, (Kartahadimaja et al. 2013).

Hasil penelitian Dewi (2015) Menunjukkan bahwa kombinasi lokasi dan waktu penyimpanan memberikan pengaruh yang berbeda terhadap pertambahan kadar air dan bobot benih, tetapi tidak berpengaruh nyata terhadap daya tumbuh benih dan kerusakan benih. Penyimpanan tiga bulan memberikan pertambahan kadar air dibanding dengan kontrol dan penyimpanan selama satu bulan.

Salah satu faktor yang dapat menurunkan mutu dan kualitas benih ialah kadungan air yang ada dalam benih (kadar air benih), untuk itulah penurunan kadar air benih sangatlah penting untuk dilakukan. Salah satu upaya untuk mengatasi penurunan mutu dan kualitas benih yaitu dengan cara pengeringan dengan menggunakan metode penyimpanan (kering lumbung), selain tidak mengganggu aktifitas dan waktu istirahat juga dapat mencegah dari serangan hewan serta mencegah kerusakan embrio saat pengeringan. Metode penyimpanan (kering lumbung) sudah sejak lama dilakukan oleh masyarakat lokal untuk menyimpan hasil panen yang akan digunakan sebagai bahan tanaman di musim tanam berikutnya, (Mustakim et al., 2020).

Tujuan dari penelitian ini ialah untuk mendapatkan penanganan pasca panen terbaik dengan metode penyimpanan yang berbeda untuk menghasilkan benih yang bermutu dan berkualitas dengan perkecambahan terbaik

\section{Metode penelitian}

Penelitian ini dilaksanakan di Desa tamarenja (lembah kalama), Kecamatan Sindue Tobata, Kabupaten Donggala pada ketinggian tempat 180-250 Mdpl, serta pengujian kecambah dilaksankan di Laboratorium Ilmu dan Teknologi Benih, Fakultas Pertanian, Universitas Tadulako. Penelitian ini dilaksanakan pada bulan Oktober 2019 sampai Februari 2020.

Alat yang digunakan antara lain cawan petri, pinset, plastik, kertas label, alat perkecambahan, kamera dan alat tulis menulis. Bahan yang digunakan antara lain benih padi gogo kultivar Kalendeng yang baru dipanen dan kertas merang.

Penelitian ini disusun menggunakan racangan acak kelompok (RAK) pola faktorial dua faktor, faktor pertama terdiri atas dua tempat penyimpanan yaitu: $\mathrm{P} 1=$ Penggantungan dalam ruangan, $\mathrm{P} 2=$ Penggantungan luar ruangan, Sedangkan faktor kedua terdiri atas tiga waktu penyimpanan yaitu: W1=Penyimpanan satu bulan, W2= Penyimpanan dua bulan, dan W3= Penyimpanan tiga bulan, yang diulang sebanyak enam kali sehingga terdapat 36 unit percobaan dimana setiap unit percobaan terdapat 50 benih dan total benih yang digunakan ialah sebanyak 1.800 benih.

Penelitian ini diawali dengan memanen padi gogo kultivar Kalendeng dan langsung menggantungnya di dua tempat yang berbeda dengan lama waktu penggantungan selama tiga bulan sebagai perlakuan (penggantungan dalam ruangan dan luar ruangan). Perkecambahan benih dilakukan setiap bulannya selama tiga bulan berturut-turut.

Perkecambahan benih menggunakan uji diatas kertas merang. Parameter yang diamati 
Jurnal agrotech 10 (2) 48-53, Desember 2020

ialah sebagai berikut: daya berkecambah, potensi tumbuh, waktu berkecambah, persentase benih berjamur dan persentase kecambah berjamur dihitung pada hari ke 14 dengan menggunakan rumus, (Sadjad, 1997; Sadjad et al.,1999; Sutopo, 2002).

$\mathrm{DB}=\frac{\text { Benih yang berkecambah normal }}{\text { Benih yang dikecambahkan }} \times 100$

$\mathrm{PTM}=\frac{\text { Benih yang berkecambah }}{\text { Benih yang dikecambahkan }} \times 100$

Waktu berkecambah $=\frac{\mathrm{N} 1 . \mathrm{T} 1+\mathrm{N} 2 . \mathrm{T} 2+\cdots \mathrm{Ni} . \mathrm{Ti}}{\text { Benih yang berkecambah }}$
e-ISSN : 2621-7236

p-ISSN : 1858-134X

Keterangan:

$\mathrm{N} 1=$ Benih yang berkecambah

$\mathrm{T} 1=$ Hari berkecambah

$\mathrm{Ni}=$ Benih berkecambah hari berikutnya

$\mathrm{Ti}=$ Hari berkecambah berikutnya

$$
\begin{aligned}
& \text { Benih berjamur }=\frac{\text { Jumlah Benih berjamur }}{\text { Total benih dikecambah }} \times 100 \\
& \text { Benih berjamur }=\frac{\text { Jumlah Kecambah berjamur }}{\text { Total benih berkecambah }} \times 100
\end{aligned}
$$

Data hasil perhitungan dianalisis menggunakan analisis ovarian (Anova), dan dilanjutkan dengan uji BNJ taraf $1 \%$ untuk mengetahui perbedaan antar perlakuan

\section{Hasil dan Pembahasan}

\section{Hasil}

Daya Berkecambah

Tabel 1. Nilai rata-rata daya berkecambah $(\%)$

\begin{tabular}{ccccc}
\hline \multirow{2}{*}{ Tempat Penyimpanan } & \multicolumn{4}{c}{ Lama Waktu Penyimpanan } \\
\cline { 2 - 5 } & Satu Bulan & Dua Bulan & Tiga Bulan & BNJ 1\% \\
\hline Dalam ruangan & ${ }_{\mathrm{p}} 11,00^{\mathrm{a}}$ & $\mathrm{p}^{5} 50,33^{\mathrm{b}}$ & $\mathrm{p}_{\mathrm{p}} 67,33^{\mathrm{c}}$ & 4,89 \\
Luar ruangan & $\mathrm{q}^{2} 29,00^{\mathrm{a}}$ & $\mathrm{q}_{\mathrm{q}} 70,00^{\mathrm{b}}$ & ${ }_{\mathrm{p}} 71,00^{\mathrm{b}}$ & \\
\hline BNJ 1\% & 5,61 & \\
\hline Keterangan: & Angka yang diikuti dengan huruf yang sama tidak menunjukan perbedaan dan angka yang diikuti \\
dengan huruf yang berbeda itu menunjukkan perbedaan.
\end{tabular}

Hasil uji BNJ pada taraf $1 \%$ menunjukkan bahwa perlakuan lama waktu penyimpanan tiga bulan menghasilkan daya berkecambah lebih tinggi baik penyimpanan didalam ruangan atau pun luar ruangan dan berbeda nyata dengan penyimpanan dibulan pertama dan kedua baik dalam atau pun luar ruangan.

\section{Waktu Berkecambah}

Hasil uji BNJ pada taraf $1 \%$ menunjukkan bahwa perlakuan lama waktu penyimpanan di dalam ruangan memberikan waktu berkecambah tercepat pada bulan ke dua dan berbeda nyata dengan penyimpana bulan pertama dan kedua. Penyimpanan diluar ruangan yang disimpan selama tiga bulan menghasilkan waktu berkecambah lebih cepat dan berbeda nyata dengan penyimpanan pada bulan pertama dan kedua (Tabel 2).

\section{Potensi Tumbuh Maksimum}

Hasil uji BNJ pada taraf $1 \%$, menunjukan bahwa benih yang simpan selama dua bulan baik didalam ruangan maupun luar ruangan menghasilkan potensi tumbuh tertinggi dan berbeda nyata dengan penyimpanan bulan pertama dan ketiga baik dalam ruangan maupun luar ruangan (Tabel 3).

Tabel 2. Nilai rata-rata waktu berkecambah (hari)

\begin{tabular}{ccccc}
\hline \multirow{2}{*}{ Tempat Penyimpanan } & \multicolumn{4}{c}{ Lama Waktu Penyimpanan } \\
\cline { 2 - 5 } & Satu Bulan & Dua Bulan & Tiga Bulan & BNJ 1\% \\
\hline Dalam ruangan & ${ }_{\mathrm{q}}^{5,66^{\mathrm{c}}}$ & $\mathrm{p}^{2}, 22^{\mathrm{a}}$ & $\mathrm{q}^{3}, 01^{\mathrm{b}}$ & \multirow{2}{*}{0,19} \\
Luar ruangan & $\mathrm{p}^{4}, 81^{\mathrm{c}}$ & $\mathrm{p}^{2}, 43^{\mathrm{b}}$ & $\mathrm{p}^{2}, 23^{\mathrm{a}}$ & \\
\hline BNJ 1\% & & 0,22 & \\
\hline
\end{tabular}

Keterangan: Angka yang diikuti dengan huruf yang sama tidak menunjukan perbedaan dan angka yang diikuti dengan huruf yang berbeda itu menunjukkan perbedaan 
Tabel 3. Nilai rata-rata potensi tumbuh maksimum (\%)

\begin{tabular}{|c|c|c|c|c|}
\hline \multirow{2}{*}{ Tempat Penyimpanan } & \multicolumn{4}{|c|}{ Lama Waktu Penyimpanan } \\
\hline & Satu Bulan & Dua Bulan & Tiga Bulan & BNJ $1 \%$ \\
\hline Dalam Ruangan & ${ }_{\mathrm{q}} 70,67^{\mathrm{a}}$ & $\mathrm{p} 87,33^{\mathrm{c}}$ & $\mathrm{p} 81,33^{\mathrm{b}}$ & 26 \\
\hline Luar Ruangan & p $51,67^{\mathrm{a}}$ & $p 85,67^{\mathrm{c}}$ & $\mathrm{p} 80,33^{\mathrm{b}}$ & 3,61 \\
\hline
\end{tabular}

Keterangan: Angka yang diikuti dengan huruf yang sama tidak menunjukan perbedaan dan angka yang diikuti dengan huruf yang berbeda itu menunjukkan perbedaan.

\section{Persentase Benih Berjamur}

Tabel 4. Nilai rata-rata persentase benih berjamur (\%)

\begin{tabular}{ccccc}
\hline \multirow{2}{*}{ Tempat Penyimpanan } & \multicolumn{4}{c}{ Lama Waktu Penyimpanan } \\
\cline { 2 - 5 } & Satu Bulan & Dua Bulan & Tiga Bulan & BNJ 1\% \\
\hline Dalam Ruangan & ${ }^{2} 29,33^{\mathrm{b}}$ & ${ }_{\mathrm{q}} 12,67^{\mathrm{a}}$ & ${ }_{\mathrm{p}} 12,00^{\mathrm{a}}$ & 2,90 \\
Luar Ruangan & $\mathrm{q}^{45,67^{\mathrm{b}}}$ & $\mathrm{p}^{\mathrm{a}}, 33^{\mathrm{a}}$ & $\mathrm{p}^{9} 9,33^{\mathrm{a}}$ & \\
\hline BNJ1\% & & 3,33 & & \\
\hline
\end{tabular}

Keterangan: Angka yang diikuti dengan huruf yang sama tidak menunjukan perbedaan dan angka yang diikuti dengan huruf yang berbeda itu menunjukkan perbedaan

Hasil uji BNJ pada taraf $1 \%$ menunjukkan bahwa benih yang di simpan selama tiga bulan baik di dalam ruangan maupun di luar rungan menghasilkan nilai rata-rata persentase benih

\section{Persentase Kecambah Berjamur}

Tabel 5. Nilai rata-rata persentase kecambah berjamur (\%)

\begin{tabular}{ccccc}
\hline \multirow{2}{*}{ Tempat Penyimpanan } & \multicolumn{4}{c}{ Lama Waktu Penyimpanan } \\
\cline { 2 - 5 } & Satu Bulan & Dua Bulan & Tiga Bulan & BNJ1\% \\
\hline Dalam Ruangan & ${ }_{\mathrm{q}} 59,67^{\mathrm{c}}$ & ${ }_{\mathrm{p}} 19,00^{\mathrm{b}}$ & ${ }_{\mathrm{q}} 14,00^{\mathrm{a}}$ & 4,03 \\
Luar Ruangan & ${ }_{\mathrm{p}} 21,00^{\mathrm{c}}$ & ${ }_{\mathrm{p}} 15,67^{\mathrm{b}}$ & ${ }_{\mathrm{p}} 9,33^{\mathrm{a}}$ & \\
\hline BNJ1\% & 4,62 \\
\hline Keterangan: & Angka yang diikuti dengan huruf yang sama tidak menunjukan perbedaan dan angka yang diikuti \\
dengan huruf yang berbeda itu menunjukkan perbedaan
\end{tabular}

Hasil ujin BNJ pada taraf $1 \%$ menunjukkan bahwa benih yang di simpan selama tiga bulan baik dalam ruangan maupun di luar rungan menghasilkan nilai rata-rata persentase kecambah berjamur paling sedikit dan berbeda nyata dengan penyimpanan bulan pertama dan ke dua.

\section{Pembahasan}

Hasil penelitian menunjukkan bahwa lama waktu penyimpanan serta tempat penyimpanan memberikan pengaruh yang sangat nyata terhadap variabel yang diamati. Benih padi gogo yang di simpan selama 3 bulan menghasilkan nilai ratarata daya berkecambah (penyimpanan di dalam berjamur paling sedikit dan berbeda nyata dengan perlakuan lain, kecuali perlakuan penyimpanan selama dua bulan, baik diluar maupun di dalam ruangan. dan di luar ruangan), waktu berkecambah (penyimpanan di luar ruangan) terbaik, serta persentase benih berjamur dan kecambah berjamur paling rendah baik di dalam maupun di luar ruangan.

Hal ini membuktikan bahwa semakin lama hasil panen padi gogo yang disimpan dilumbung maka semakin baik untuk dijadikan benih. Benih padi gogo yang disimpan selama 3 bulan dapat meningkatkan viabilitas dan vigor benih padi. Hasil penelitian yang dilakukan oleh (Mustakim et al., 2020) menemukan bahwa Waktu penyimpanan terbaik yaitu penyimpanan selama 2 bulan dimana menghasilkan daya berkecambah 
dan potensi tumbuh tertinggi, serta waktu berkecambah yang lebih cepat. Penelitian juga dilakukan oleh (Anna, 2017) yang menemukan bahwa periode simpan benih padi yang dapat meningkatkan viabilitas dan vigor benih adalah periode simpan 3 bulan.

Viabilitas benih dapat diukur dengan tolak ukur daya kecambah (germination capacity), (copeland and Donald, 2001). Vigor merupakan sejumlah sifat-sifat benih yang mengindikasikan pertumbuhan dan perkembangan kecambah yang normal, cepat dan seragam pada kondisi yang optimum maupun sub optimum (Anna, 2017).

Penurunan dan peningkatan perkecambahan (waktu berkecambah dan potensi tumbuh maksimum) yang disimpan didalam dan luar ruangan pada bulan kedua dan ketiga diakibatkan oleh kadar air benih yang berubah-ubah, dimana benih bersifat higroskopis, yang artinya benih mudah menyerap air yang ada dilingkangan luar benih jika kadar air benih lebih rendah dibanding kelembaban udara.

Menurut (Hendarto, 2007) bahwa benih bersifat hogroskopis (mudah menyerap air) dan selalu mencapai kondisi equilibrium dengan lingkungannya. Dewi, (2015) juga menyatakan ketika kelembaban udara tempat penyimpanan benih sangat tinggi dimana kadar airnya lebih tinggi dari pada kadar air benih, maka benih akan menyerap kadar air dari udara sehingga kandungan airnya juga meningkat. Menurut (Dinarto, 2010) menyatakan Kelembaban relatif udara sekitar benih meningkat (tinggi), maka kadar air benih akan meningkat pula sampai terjadinya nilai keseimbangan antara kadar air benih danga kelembaban relatif udara sekitar

Potensi tumbuh maksimum menghasilkan nilai rata-rata terbaik pada bulan kedua dan ketiga, dimana persentase benih yang berkecambah masih diatas $80 \%$. Departemen Pertanian, menyebutkan bahwa persyaratan mutu di laboratorium diantaranya yaitu untuk kadar persyaratan mutu maksimum $13 \%$ sedang untuk daya kecambah atau daya tumbuh persyaratan mutu minimumnya sebesar $80 \%$. Kemampuan berkecambah suatu benih berhubungan dengan banyaknya cadangan makanan yang dikandungnya (Sadjad et al., 1999). Tolak ukur potensi tumbuh, daya berkecambah benih yang di dukung oleh laju perkecambahan mengindikasikan vigor dan viabilitas benih tersebut baik (Mustakim et al., 2017).

Kelembaban yang tinggi serta suhu udara yang rendah menyebabkan kemunduran viabilitas benih dapat di kurangi, sehingga daya simpan benih bisa lebih lama, saat suhu rendah aktivitas metabolisme menjadi berkurang. Menurut (Fahn, 1995) bahwa metabolisme di dalam benih di kendalikan oleh kerja enzim yang tersusun dari protein-protein sehingga dengan suhu rendah akan menghambat kerja enzim. Penyimpana benih padi yang baik dan benar akan dapat mempertahankan kualitas benih padi selama kurun waktu tertentu (Rahayu et al., 2011).

Hasil penelitian menunjukkan bahwa persentase kecambah berjamur mengalami penerunan hingga pada penyimpanan 3 bulan. Hal ini dikarenakan semakin lama penyimpanan dilakukan dapat menurunkan kadar air benih. Kadar air benih dapat menjadi pemicu serangan jamur dan bakteri yang menyebabkan benih dan kecambah berjamur. Hasil penelitian yang dilakukan oleh (Mustakim et al., 2020) menemukan bahwa penyimpanan selama 2 bulan dapat menurunkan persentase benih dan kecambah berjamur menjadi lebih sedikit.

\section{Kesimpulan dan Saran}

\section{Kesimpulan}

Bedasarkan hasil penelitian dapat disimpilkan bahwa penanganan pasca panen dengan metode peyimpanan (kering lumbug) yang terbaik ialah penyimpanan diluar ruangan dengan lama penyimpanan tiga bulan karena menghasilkan daya berkecambah $(71.00 \%)$, waktu berkecambah (2.23 hari), persentase benih berjamur $(9.33 \%)$ dan kecambah berjamur $(9.33 \%)$.

\section{Saran}

Perlu dilakukan penelitian lanjutan dengan menambah lama waktu penyimpanan agar dapat menghasilakan daya berkecambah $\geq 80 \%$.

\section{Daftar Pustaka}

Anna, T., 2017. Uji Viabilitas dan Vigor Benih Padi (Oryza sativa, L) selama Penyimpanan pada Tingkat Kadar Air yang Berbeda. Savana Cendana. 2(3): 48-50.

Copeland, L.O, and M.B.Mc. Donald, 2001. Principles of Seed Science and Teknology. Burgess Publishing Company. New york. $369 \mathrm{p}$.

Dewi, K.T., 2015. Pengaruh Kombinasi Kadar Air Benih dan Lama Penyimpanan Terhadapa Viabilitas dan Sifat Fisik Padi Sawah Kultivar Ciherang. Jurnal Agrorektan 2(1): 53-61. 
Dinarto, W., 2010. Pengaruh Kadar Air dan Wadah Simpan Terhadap Viabilitas Benih Kacang Hijau dan Populasi Hama Kumbang Bubuk Kacang Hijau (Callosobruchus Chinensis L.) Jurnal AgriSains 1(1): 68-78.

Fahn, A., 1995. Anatomi Tumbuhan. Penerjemah: Soediarto, A. Yogyakarta: Universitas Gadjah Mada Press.

Hendarto, K., 2007. Teknologi Pemrosesan Pengemasan da Penyimpanan Benih. Kanisius. Yogyakarta

Kartahadimaja, J., E. E. Syuriani, dan N.A. Hakim, 2013. Pengaruh Penyimpanan Jangka Panjang (Long Term) Terhadap Viabilitas Dan Vigor Empat Galur Benih Inbred Jangung. Jurnal Penelitian Pertanian Terapan 13(3): 168-73.

Mustakim, Maemunah, and Adrianton, 2017. Uji Drought Tolerance Test of Three Gogo Rice Cultivars Using Peg Atgermination Phase. Agroland: The Agriculture Science Journal. 4(2): 98-103.

Mustakim, S. Samudin, Maemunah, Adrianton, dan Yusran, 2020. Improvement of Gogo Rice Seeds Through Adaptive Locations and Storage. Agroland: The Agriculture Science Journal. 7(1): 54-60.

Putra, O.D., S. Samudin, dan I. Lakani, 2014.
Karakterisasi Genotip Padi Lokal Kamba Asal Dataran Lore. Agrotekbis. 2(2): 146154.

Rahayu, S., W.P. Yeyen, dan K. Mahargono, 2011. Penyimpanan Benih Padi Menggunakan Berbagai Jenis Pengemas. Jurnal Agrin. 15(1).

Sadjad, S., 1997. Membangun Industri Benih Dalam Era Agribisnis Indonesia. Gramedia. PT. Jakarta.

Sadjad, S., E. Murniati, dan S. Ilyas, 1999. Parameter pengujian vigor benih dari komparatif ke simulatif. Grasindo dan PT Sang Hyang Seri. Jakarta.

Samudin, S., Maemunah, Adrianton, Mustakim, dan Yusran, 2020. Daya Hasil Beberapa Kultivar Padi Gogo Lokal Asal Kabupaten Tojo Una-Una dan Sigi. Agroland: Jurnal Ilmu-Ilmu Pertanian. 27(2): 183-190.

Sarwanto, S. Samudin., dan A. Ete, 2018. Karakterisasi Beberapa Kultivar Padi Gogo Lokal. Agrotekbis. 6(2): 274-284

Sutaryo, B., dan D.H. Pamungkas, 2019. Penampilan Hasil Gabah Dan Komponen Agronomi Padi Hibrida Di Godean, Sleman, Yogyakarta. Jurnal Ilmiah Agroust 1(1): 106-15.

Sutopo, L., 2002. Teknologi Benih. Jakarta: PT. Raja Grafindo Persada. 